\title{
Chapter 3 \\ Intellectual Property and Licensing Strategies in Open Collaborative Innovation
}

\author{
Marcel Bogers \\ University of Southern Denmark, Denmark \\ Rudi Bekkers \\ Eindhoven University of Technology, The Netherlands \\ Ove Granstrand \\ Chalmers University of Technology, Sweden
}

\begin{abstract}
Protecting intellectual property and controlling the use of their inventions is key to the strategy of many firms. At the same time, in order to be successful in open collaborative innovation, firms need to share their knowledge with others. This chapter presents, for moderate specialists, some strategic considerations with respect to managing intellectual property in open collaborative innovation. The chapter discusses how licensing strategies can be employed to balance various goals in collaborative efforts to innovate. In particular, licensing of intellectual property is presented as a way to manage protected knowledge that is developed and shared in collaborative innovation. Different elementary licensing schemes are presented. Open collaborative innovation can then consist of various "modules" of elementary licenses. The chapter finally proposes a few distinct strategies for governing knowledge exchange in collaborative innovation, including open exchange and layered schemes, thereby outlining some conditions for successful open collaborative innovation.
\end{abstract}




\section{INTRODUCTION}

Firms increasingly rely on external stakeholders to successfully innovate, as for example shown by the growing importance of inter-firm partnership and open innovation more generally (Dahlander \& Gann, 2010; Hagedoorn, 2002). Building on the increasing importance of open innovation, as a means to use and recombine internal and external knowledge to develop and commercialize valuable innovations (Chesbrough, 2003a), patent and know-how licensing and technology markets in general have become more important as a means to appropriate the benefits from innovation (Arora, Fosfuri, \& Gambardella, 2001; Granstrand, 2000, 2004). As such, the question how to manage intellectual property(IP) is becoming increasingly important as more firms develop their open innovation strategies (Alexy, Criscuolo, $\&$ Salter, 2009; Chesbrough, 2003b).

Within the context of open innovation, there is moreover increasing recognition of a "coupled" process of open innovation in which firms cocreate innovations with other stakeholders (e.g. through R\&D collaborations) in which they need to cooperate and thus both obtain and share knowledge (Bogers \& West, 2010; Enkel, Gassmann, $\&$ Chesbrough, 2009). Such open collaborative innovation therefore challenges firms and their collaborators in terms of protecting their knowledge and IP more generally.

As a central part of their open innovation strategy, firms should thus manage their IP portfolio by extracting value from internal knowledge and intellectual property rights (IPRs), while also acknowledging that protection at the same time may hamper innovativeness, adoption and diffusion.

To address the above issues, this chapter first provides an overview of the key elements related to the protection and control of knowledge, thereby also developing an overview of distinct licensing opportunities. Based on this, it subsequently proposes a number of strategies as ways to govern knowledge exchange in open innovation. As such, this chapter provides a typology of basic licensing schemes that can serve as building blocks for more complex licensing arrangements.

\section{KNOWLEDGE PROTECTION AND INTELLECTUAL PROPERTY}

As open innovation in general and collaborative innovation in particular have increased in both extent and importance, protecting the knowledge that is being shared has become an increasingly important but also challenging issue for the innovating organizations. There are several trends that exemplify the growing importance of knowledge protection in general. For example, the growing importance of IP can be seen in the increasing number of patent applications (Granstrand, 2000; Grindley \& Teece, 1997). That is, the rise of a "pro-IP era" or "pro-patent era" (Granstrand, 2000; Jaffe, 2000) has lead to an increasing propensity for firms to file patents (e.g. Grindley \& Teece, 1997)—now often considered as being a firm's "crown jewels" among its assets, especially in high-technology industries (e.g. Coriat \& Orsi, 2002). As a result, this raises the importance of intellectual capitalism (IC) (see e.g. Gerlach, 1992; Teece, 2000) in general and IP/IC management in particular (Arora, et al., 2001; Chesbrough, 2003b).

However, the existing institutions of patenting and IPRs at large have received an increasing amount of criticism in recent years (e.g. Boldrin \& Levine, 2008; Coriat \& Orsi, 2002; Dosi, Marengo, $\&$ Pasquali, 2006), thus also giving rise to new and often less protective strategies - not the least in the context of open innovation, e.g. in relationship to open source software (Henkel, 2006; Mazzoleni \& Nelson, 1998; Shapiro, 2001; von Hippel \& von Krogh, 2003). Moreover, there are indications that the transaction costs and societal costs of the patent system are increasing, which creates the need to reconsider the present patenting and licensing approaches (e.g. Davis, 2004; Jaffe \& Lerner, 2004; Mazzoleni \& Nelson, 1998). It has been argued that 
the legal provisions in the current patent regime are to a large extent over-protective, which may result in a slowdown in innovation, for example in software technologies (Harison, 2004). It has furthermore been argued that "patent thickets" "patent jungles" arise in some technologies and industries, creating an anti-commons, hold-ups, dead-locks and associated IP assembly problems, which in turn can have important anti-competitive (or anti-trust) implications and can hamper innovation and dynamic competition (Granstrand, 2000, 2003; Heller \& Eisenberg, 1998). Patents can then be licensed, cross-licensed, and pooled, in order to accommodate certain developments, e.g. in relation to certain standardization efforts in which IPRs and agreements like non-disclosure agreements (NDAs), joint venture agreements (JVAs) and licenses can then be used to set useful rules of the game in open collaborative innovation (Andersen, 2004).

To spur open collaborative innovation, the effectiveness of the design of the IPR system depends on the ease (e.g. low transaction costs) with which right holders can enter into licensing and other contractual arrangements involving these rights (Gallini \& Scotchmer, 2002) and its functionality as a contractual infrastructure for market signaling and governance. Furthermore, licensing has become of growing importance, partly due to the rise of patenting propensity and strategic patenting, using various patent strategies (fences, thickets, blankets, evergreening, multi-protection, etc). This requires firms to increasingly acquire multiple licenses to avoid risks of litigation when they commercialize an innovation (Granstrand, 2000, 2004; Hertzfeld, Link, \& Vonortas, 2001; Shapiro, 2001).

With these trends as background, the next section discusses the properties of knowledge in general and technical knowledge (i.e. technology) in particular, as well as the rationale for knowledge and technology protection in inter-organizational collaborative innovation. It subsequently describes proprietary knowledge as a form of IP and gives an overview of different IP strategies in general and for open collaborative innovation in particular. It concludes by providing an overview of various licensing schemes and strategies, as a particular way to share protected knowledge in open collaborative innovation.

\section{PROPERTIES OF KNOWLEDGE AND TECHNOLOGY}

When considering how to protect knowledge - in particulartechnical knowledge (i.e. technology) in open collaborative innovation, a useful point of departure is an exposition of some elementary properties of knowledge and technology.

In principle, knowledge can be considered as a partly public good, as noted by e.g. Arrow (1962) and others, with two main properties being that it is (a) non-rivalrous in consumption and (b) non-excludable. As a public good, knowledge has high fixed costs in production and low costs in distribution. The production and distribution of knowledge, in its pure form, is moreover cumulative and interactive, while it is also impossible to reverse the process of knowledge transfer (dispossession is impossible). However, in reality, the public good nature of knowledge is not purely valid due to the possibility to appropriate knowledge.

Moreover, the protection of knowledge - in particular technical knowledge-is contingent on the embodiment of the knowledge, as this determines how it can be transferred and protected. For example, there are limits to the ability to identify and transfer tacit (as opposed to explicit or codified) knowledge (Cowan, David, \& Foray, 2000; Polanyi, 1958, 1967). Tacit knowledge is difficult to articulate and valuate, making it more difficult to transfer it economically (Teece, 2000). For example, open collaborative innovation usually requires joint, face-to-face communication 
to transfer knowledge properly, which can be a slow and costly process (Afuah, 2003; Conner \& Prahalad, 1996; Monteverde, 1995; von Hippel, 1994).

In the context of open collaborative innovation, however, knowledge (and technical knowledge in particular) can often be more easily transferred due to its embodiment in technologies and IPRs, although other costs need to be considered. Following Granstrand (1998), technical knowledge (i.e. technology) has specific properties. These technology properties - codifiability, cumulativeness, combinatorial and patentability — give growth potential as well as transfer, spillover and trade possibilities for technology but general knowledge properties - especially dispossession impossibility and observation impossibility for human embedded knowledge - create moral hazard, which creates knowledge market failures at the same time, as in Arrow's (1962) information paradox. This implies a need from both buyer and seller side for long-term contractual governance on the technology market, resulting in license type of contracts, be they patent or know-how licenses. This is fundamentally different from a spot market transaction with the physical transfer of a traded item with exhaustion of rights. Given the constraints of knowledge trade (as different from physical trade), together with supply and demand for new technologies, open collaborative innovation becomes more conducive (or even necessary) as a quasi-integrated organizational form - intermediate between markets and management governance - as a driver of technological innovation at firm level (see also Granstrand, 2004).

\section{A STRATEGIC PERSPECTIVE ON INTELLECTUAL PROPERTY}

\section{Intellectual Property Rights and Licensing}

IP may be considered as a form of property like "real" physical property, such as land or machinery, although the degree to which this is true has been part of a long-time discourse on the nature and legitimation of IPRs (see Machlup \& Penrose, 1950 , for a good overview). Moreover, it could be noted that historically an IPR like a patent right has not been viewed as "property" but rather as a privilege on concession. IP can be subjected to possession and control by agents and could thereby be viewed as property, although first and sole possession, being basic criteria for granting physical property rights, are difficult to establish for IP.

IP can be distinguished from physical property due to its intangibility. As such, it can be considered as a distinct form of intellectual capital. Real property has physical features making it a tangible good whereas the main characteristic of IP is its intangible nature.

The main characteristic of intellectual property (and physical property alike) is that it can be bought, sold, given away, leased and exchanged, although there are limits to do this. In essence, the owner of the property can prevent others from using the property and possibly transacting it in the ways described above by a legal framework.

According to the World Intellectual Property Organization (WIPO, 2001), IPRs refer to the legal rights which result from intellectual activity in the industrial, scientific, literary and artistic fields. Every country has its own laws to protect IP, although a process of international harmonization is ongoing. Generally, IP law aims at safeguarding creators and other producers of intellectual goods and services by granting them certain rights (for a limited amount of time) to 
control the use of their knowledge. Those rights do not apply to the physical object in which the creation may be embodied but instead to the intellectual creation as such. WIPO (2001) distinguishes two branches of IPRs, namely "industrial property" and "copyright". The latter refers to literary, artistic and scientific works, while IPRs relates to industrial property, including industrial designs, trademarks, geographical indication, trade secrets, and patents. ${ }^{2}$ In the context of open collaborative innovation, trade secrets and patents are most relevant, while they are also generally the most commonly used method of protecting IP (see e.g. Hertzfeld, et al., 2001). Moreover, in the context of open source software, copyright (or "copyleft") plays a particularly important role (de Laat, 2005; Lerner \& Tirole, 2002b; von Hippel $\&$ von Krogh, 2003). Several considerations that relate to obtaining certain IPRs, such as patents, include the likelihood of patent protection, the life cycle of the technology, the relation to other IPRs, risk of losing the protection, the cost of obtaining, maintaining and enforcing the protection, the technology readiness, and the licensing possibilities (Lee \& Davidson, 1993).

Because of the importance of patents in general and in open collaborative innovation in particular, understanding the main strategies to exploit patents is of interest within the context of collaborative innovation and open innovation more generally. Once an organization (or individual) is granted a patent, it basically needs to make some strategic choices.

The first one is whether to allow others to use the patented technology. If the company decides to do so, it can sell its patent altogether (e.g. if it does not want to be liable for litigation or lost interest in owning it). Alternatively, it could opt to license its patent out, in order to raise licensing revenue, or to gain access to other party's intellectual property via cross-licenses. Well-known examples of licensed technologies are Xerox' Ethernet technology and JVC's VHS technology. It could be noted that any type of IPR could be licensed, such as in high-tech industries, software and science, but in the music industry as well. Below, we will discuss licensing strategies in greater detail.

If a company decides it does not want others to use the patented technology, it still has to decide whether or not it actually wants to implement the patented technology itself in its products or processes. Philips' use of its shaving technology patents is an example in which it uses its patents to enjoy a monopoly on some specific technologies, offering Philips a particular competitive advantage. But also not implementing the patented technology is not an unusual strategy. Firms may want to have a patent to block the development of a rivaling technology of a competitor or to keep the option to enter a market at a later stage.

\section{Licensing Types: Building Blocks for IP Strategies}

Given the important role played by patents as well as technology and IP more generally, licensing strategies are central to understanding the possible constraints to knowledge transfer in open collaborative innovation. Licensing is a transfer of rights from a licensor (seller), typically the owner of an IPR, to a licensee (buyer). For the former it is a means to exploit its IP while at the same time controlling its use or diffusion. The latter can use the IP without having to fear it is infringing the underlying IPR (e.g. patent). The licensor can license out all or just some of the rights and will consider which restrictions to use.

Two of the main considerations in relation to licensing are exclusivity and whether the licensee has the right to sublicense. Licenses might moreover apply to different types of knowledge, with an important consideration being whether the knowledge is developed before, during, besides and after the collaboration (cf. European Commission, 2001, 2002). Accordingly, Table 1 distinguishes between background, foreground, sideground and postground knowledge (Bogers, 2011). 
Below follow some of the different considerations regarding licensing and some different (general) licensing forms will be discussed. Most of the licensing types presented below should be considered as essentially being "modules" of (elementary) licenses, which can in turn be used as building blocks to be combined to form more complex licensing "architectures" as one could expect in open collaborative innovation. ${ }^{3}$ See Figure 1 for an overview of different types of licenses (see also Granstrand, 2011).

In order to benefit from licensing - thus going beyond the base case in which the owner of the IPR keeps the rights (i.e. self-license) - the licensor may demand a compensation from the licensee, as in an exclusive, sole or simple (nonexclusive) license as basic licensing types (Figure 1). In the more ordinary, traditional way of licensing, the payment of royalties can be seen as a good means of compensation. The concept of royalty means that the licensee pays a fee to use the licensor's knowledge under the conditions stated in the licensing agreement. Different kinds of monetary royalties that can be distinguished are, for example, lump sum payment, fixed payment per sold product, fixed fee per year, percentage of sales price or revenues, or a gradual payment that changes per sales volume.

Table 1. Types of knowledge open collaborative innovation (Bogers, 2011)

\begin{tabular}{|l|l|}
\hline \multicolumn{1}{|c|}{$\begin{array}{c}\text { Type of } \\
\text { knowledge }\end{array}$} & \multicolumn{1}{c|}{ Description } \\
\hline $\begin{array}{l}\text { Background } \\
\text { knowledge }\end{array}$ & $\begin{array}{l}\text { Existing knowledge put into the collabora- } \\
\text { tion }\end{array}$ \\
\hline $\begin{array}{l}\text { Foreground } \\
\text { knowledge }\end{array}$ & $\begin{array}{l}\text { Knowledge created as an outcome of the } \\
\text { collaboration }\end{array}$ \\
\hline $\begin{array}{l}\text { Sideground } \\
\text { knowledge }\end{array}$ & $\begin{array}{l}\text { Knowledge relevant to the collaboration } \\
\text { developed in-house in parallel to the col- } \\
\text { laboration }\end{array}$ \\
\hline $\begin{array}{l}\text { Postground } \\
\text { knowledge }\end{array}$ & $\begin{array}{l}\text { Knowledge relevant to the collaboration } \\
\text { developed in-house by the firm after the } \\
\text { collaboration (formally) finished }\end{array}$ \\
\hline
\end{tabular}

An important consideration in relation to licensing is the exclusivity of the right. On the one hand, a licensor can grant an exclusive license by licensing to only one licensee and, on the other hand, it can grant a license to several licensees. Whichever option is considered, it has important implications for the negotiations and expected compensation. Some possible restrictions are: no right to sub-licensing or reselling (see below), geographical area, field of application, or a specific mode of commercialization (see e.g. Bessy \& Brousseau, 1998). In addition, an exclusive right for a limited period of time could be granted.

Alternatively, the licensor may demand to be compensated in other non-monetary ways, such as access to the licensee's technology. With particular reference to open collaborative innovation, if two parties are interested in each other's knowledge and both of them have an IPRs portfolio of interest to each other, they could agree on a cross-license arrangement (Figure 1). In this agreement, the parties go into a mutual agreement granting each other (a package or bundle of) licenses. Essentially, the firms license each other with the compensation being a license, or a package of licenses. Although cross-licensing principally can involve the exchange of the right to one technology from each firm, the firms most typically cross-license each other a bundle of rights. In general, the rationale for cross-licensing is to increase simplicity and decrease transaction costs. Moreover, cross-licensing can create a framework in which firms can access each other knowledge and thereby (collaboratively) create new knowledge or networks. The knowledge subject to the cross-licensing scheme can be either related or unrelated, which influences the exact terms. The (a)symmetry of the firms' packages affect the exact terms as well and potentially creates the need for additional compensation (of one party).

Another important strategic consideration is whether the licensee is allowed to sub-license, meaning that the licensee itself is allowed to grant licenses (to the licensed technology) to third parties 
Intellectual Property and Licensing Strategies in Open Collaborative Innovation

Figure 1. Types of licenses in open collaborative innovation (Granstrand, 2011)

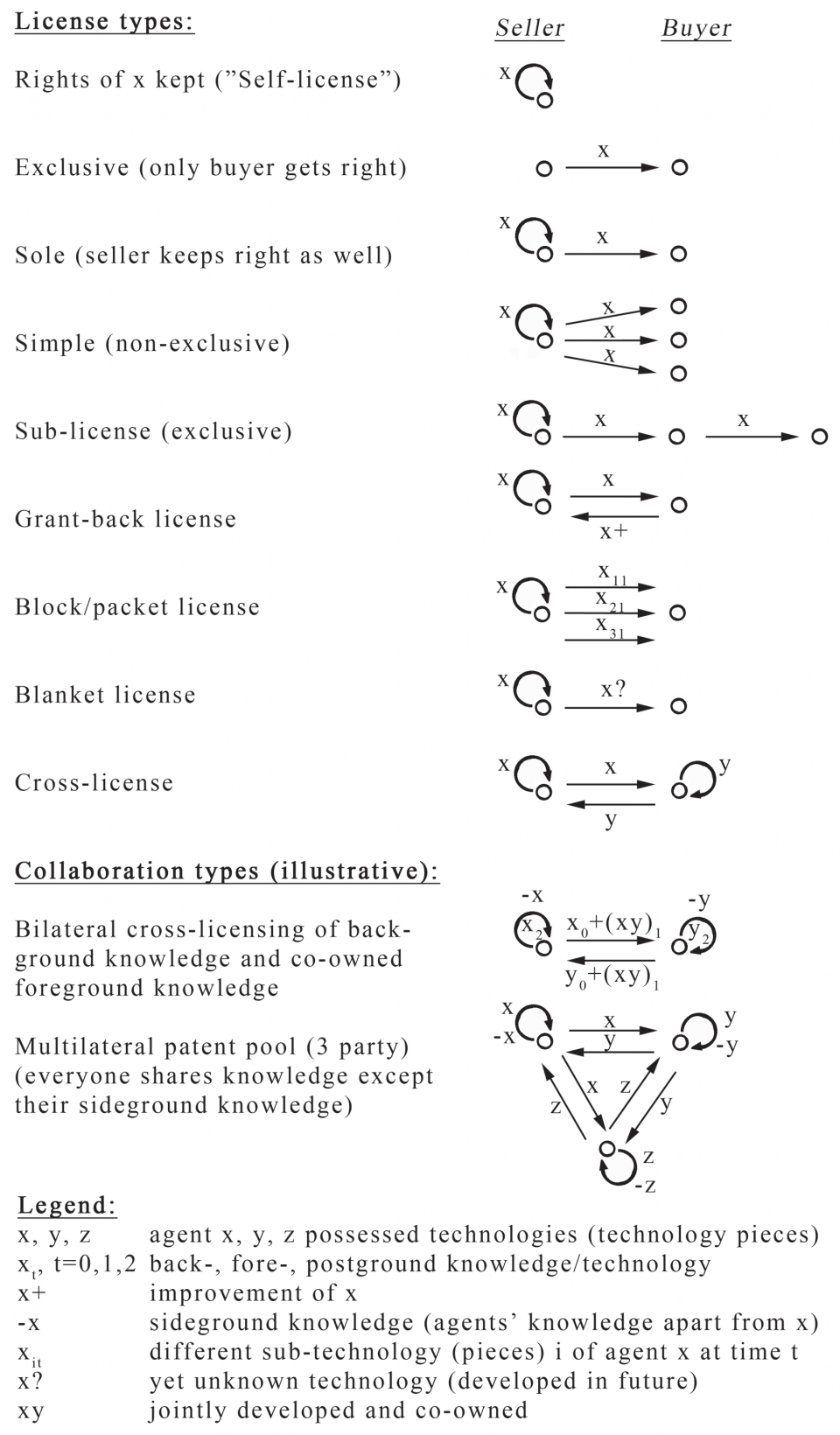

(Figure 1). The decision to allow sub-licensing depends on what the licensor wants to achieve by licensing the knowledge. For example, if the owner of an IPR is not able to fully exploit a technology, it can for this reason grant an (exclusive) license to a licensee that will commercialize the technology. In order for the licensee to be able to appropriately exploit the technology, sub-licensing could then be part of the agreement (Megantz, 1996). This strategic decision can give the main licensor the ability to profit from its technology when it does not have the resources to internally 
commercialization the technology (cf. Enkel, et al., 2009; Lichtenthaler, 2005; Lichtenthaler \& Ernst, 2007; van de Vrande, de Jong, Vanhaverbeke, \& de Rochemont, 2008). As such, sub-licensing may optimize the overall revenues from a patent. However, if a patent owner is seeking to control the use of its technology, it will avoid sub-licensing.

Moreover, in a blanket license, a licensor licenses out all rights related to the (currently unknown) future developments in a certain area. Thus, if future developments that fulfill certain criteria lead to new patents and know-how, the rights to use these are automatically granted within the blanket license agreement - in contrast to "off the shelf" licensing of existing technologies and licensing on order (or not) of future new technologies. Blanket licensing might apply to research joint ventures or alliances in which a party is licensing out its future foreground technology, while it is also embedded in some open source software agreements in which some people agree to share with some people all they come up with, before it is known or even specified or asked for.

An owner of IPRs can also consider packaging (block/package license) the rights to several technologies as a package (Figure 1). In this case, the licensee has to buy the full package of licenses in order to access one or more of the individual rights. Packaging can lower transaction costs if several licenses are required to use a certain technology. It can also be a means for a licensor to create additional revenues or an attempt to influence a certain technological development.

A final possible elementary licensing type is a grant-back license (also sometimes referred to as "technology flowback"), which gives the licensor the right to use (any) possible future technological improvements that the licensee makes to the originally licensed technology, usually in combination with a compensation of some sort (Figure 1). Thus, once the licensee develops a related technology (e.g. patent), a license to the improved technology will go back to the original licensor. The right for the licensee is only related to a specific, defined technology, and the license that is being granted back is related to improvements of that same specific, defined technology. Furthermore, the two firms can decide to more specifically define the scope of the grant-back license. Some possible distinctions are granting back the property rights on the development, or just the user rights, or alternatively they could agree on just a simple information right (Bessy \& Brousseau, 1998).

\section{Collaboration Types: Implementing IP Strategies in Open Collaborative Innovation}

In order to adopt the right licensing strategy, a firm has to consider how it can best appropriate the returns form its knowledge and technology, or IP at large. While highly codified knowledge, such as a patent, may be effectively licensed, especially if it is not context-specific (Kogut \& Zander, 1993; Williamson, 1991), licensing is not always reported as the most important appropriation mode (Cohen, Nelson, \& Walsh, 2000). For knowledge purely embedded in technology, licensing could be used if it appropriates sufficient returns (Teece, 1998). Which strategy is the best will also depend on the sector in which a firm is active. The importance and efficiency of technology and patents differ across sectors and therefore also the optimal use and benefit from licensing. For example, patents are a more efficient mechanisms to protect and appropriate benefits from knowledge in the chemical industry (e.g. Levin, Klevorick, Nelson, \& Winter, 1987). In the electronics industry, where interoperability is important and where standards provide such interoperability, cross-licensing and non-exclusive, "open" licensing programs are key. Without broad access to these IPRs, the standard can simply not reach the necessary critical mass.

Licensing strategies have changed as well in the context of open innovation. There are many examples of firms opening their boundaries in 
order to strengthen their IP portfolio (see e.g. Arora, et al., 2001; Chesbrough, 2003a). The presence of an open innovation paradigm is moreover related to the growing prevalence of collaborative innovation, with particular reference to concepts as packaging and cross-licensing. In open source software, less restrictive licensing strategies can moreover be identified. This kind of model essentially entails the use of non-exclusive, royalty-free licenses with a grant-back provision. Dependent on the exact design, a form of (local) cross-licensing may moreover be adopted. A specific example of how the above licensing types can be combines into a (more complex) licensing scheme is "copyleft", which entails a non-exclusive blanket license with a compulsory non-exclusive grant-back blanket license.

Figure 1 offers two specific examples of more complex licensing arrangements as illustrations of how elementary licensing types can be used as building blocks to represent particular types of collaborative innovation. The first illustration shows a bilateral cross-licensing of background knowledge and co-owned foreground knowledge. This example reflects a typical type of alliance in which two firms enter a collaboration in which they share their background knowledge as well as the foreground developed within the collaboration. However, as also shown in the figure, the respective firms keep the rights to their sideground as well as postground knowledge. Thus, while the firms openly share knowledge within the narrow scope of the collaboration, they are more restrictive (i.e. less open) when it comes to parallel in-house developments and developments after the collaboration has ended. It could be noted however that in practice it can be difficult to identify or prove where the boundary lies between these different types of knowledge, in particular background and sideground knowledge.

The second illustration of a type of open collaborative innovation in Figure 1 is a case of what can be called joint licensing, which takes the form of a patent pool in the case of patents.
This strategy can be relevant if there are several different holders of complementary patents (or IPRs in general) that are all needed for a certain development. Essentially, joint licensing can take two forms-licensing via mutual coordination or via a third party administrator. Typically, joint licensing involves more than two firms and the licensors can also be the licensees of other licensors' technology. A patent pool in particular can be described as an agreement between two or more parties to cross-license parts of their current or future patent portfolios related to certain technologies to one another (or to third parties). The example in Figure 1 thus shows a three-party patent pool in which all knowledge except sideground knowledge is shared by all parties.

Summarizing, some of the main strategic considerations in relation to licensing are exclusivity, sub-licensing, cross-licensing, market and territorial (and other) restrictions, future developments, technical assistance, royalties, restraint of trade, and taxes. In the context of open collaborative innovation, one could effectively distinguish between background, foreground, sideground and postground knowledge as a way to separate knowledge that is respectively developed before, during, besides and after the collaboration (cf. Bogers, 2011). This distinction can namely help to separate the types of knowledge that can or should be covered by specific types of licenses. Within a collaborative innovation project, the characteristics of the innovation project moreover determine which licensing strategy can and should be adopted. For example, licensing from universities is significantly different from industrial licensing (Megantz, 1996). In general, universities take a very open or at least publishing-oriented strategy (cf. open science), although changes in this occur as well, for example due to the implementation of the Bayh-DoleAct, which encourages universities to apply for patents on the research results, while earlier the norm was to place such results in the public domain (Eisenberg, 1996; Mazzoleni \& Nelson, 1998). Given the increasing involvement 
of universities in open collaborative innovation, such an issue can have important implications for how the protection of knowledge has to be arranged.

\section{GOVERNANCE AND LICENSING STRATEGIES IN OPEN COLLABORATIVE INNOVATION}

This section develops a number of general strategies for governing the exchange of knowledge (as a particular type of IP) in open collaborative innovation - thereby feeding into the understanding of open innovation more generally (cf. Chesbrough, 2003b; West, 2003). In particular, based on the assumption that every knowledge transfer is covered by some sort of formal or informal contract, it gives an overview of the governance of effective knowledge exchange (cf. Mohr \& Sengupta, 2002) and the role of licensing (based on the previous section). There is also a particular interest in "open source" as a model of governance and licensing. The alternatives of an open knowledge exchange and a layered collaboration scheme are also discussed. Finally, this section proposes a number of distinct knowledge exchange strategies. Based on a differentiation of knowledge sharing and protection mechanisms, these strategies offer concrete propositions and boundary conditions for when a particular strategy might be more appropriate than another one, thereby further advancing the practice of collaborative innovation as well as the research into open innovation at large (cf. Enkel, et al., 2009; West, Vanhaverbeke, \& Chesbrough, 2006).

\section{Governance}

Scholars have long identified that collaborations of various sorts set up governance structure to deal with the exchange of knowledge (see e.g. Kale, Singh, \& Perlmutter, 2000; Mohr \& Sen- gupta, 2002). These governance structures to a large extent aim at reaching a satisfying level of knowledge sharing while at the same time providing an appropriate level of protection of the knowledge. The traditional way to govern knowledge exchange in open collaborative innovation is by using agreements that state what should be shared, to which extent and how it is protected - also with respect to which type of knowledge (i.e. background, foreground, sideground and postground knowledge). Choosing an appropriate governance mechanism is thus a way to manage knowledge exchange within open collaborative innovation.

Kale et al. (2000) moreover argue that building a good relationship ("relational capital") in collaborations facilitates learning through close one-to-one interaction while it at the same time minimizes the likelihood of opportunistic behavior (i.e. unilateral absorption or stealing of proprietary knowledge). Moreover, Oxley and Sampson (2004) argue that limiting the scope of the collaboration is a way to manage knowledge exchange. In that case, the amount or degree of knowledge sharing is limited in order to decrease the potential conflict sharing this knowledge. This especially applies to the case in which the protection of knowledge is a delicate issue, which is often the case when competitors collaborate.

\section{Licensing}

Licensing, as also described above, plays an important role in the governance of knowledge transactions and thereby in collaborative and open innovation in general. Accordingly, licensing can be the way to manage knowledge transfer in open collaborative innovation, for example when there might be conflicting interests. A license is namely by definition an agreement that states the terms of how a piece of knowledge is protected (and partly how it is appropriated) when it is transferred from the licensor to the licensee. There is 
a variety of different types of elementary licenses, each providing particular permissions, which can in turn be combined to form more complex and more encompassing sets of licenses (see Figure 1).

In the context of open collaborative innovation, it will typically not be economical to specify (i.e. write a license for) every transfer of knowledge. Instead, in order to decrease transaction costs, more general agreements are used that deal with several licensing issues at once. One example of this is a cross-licensing agreement in which the partners license each other the knowledge needed for the collaboration. Alternatively, a less explicit "umbrella agreement" is used, which states that knowledge should and will be shared to the extent needed and the partners will only use this in relation to the collaboration and will not internalize it privately. Still, certain terms, such as exclusivity and compensation (in case of asymmetric knowledge exchange), can be agreed upon. These general agreements are more risky in the sense of unwanted appropriation and are therefore based on trust between the partners to a large extent. This latter strategy might be a fruitful one and perhaps even necessary to be able to reach the goal of collaborative innovation projects, particularly in the face of the increasing pace of innovation as well the increasing complexity and diversity of R\&D. In relation to this, it might be required to adopt some kind of grant-back strategy as well, with or without exclusivity and/or sub-licensing rights.

There is an increasing amount of interest in the informal exchange nature of what might be called the open source movement, in particular open source software or open science. Such examples of open collaborative innovation (which however do not necessarily involve firms) often entail informal or implicit contracting/licensing (e.g. copyleft). Such arrangements are effective under certain conditions, for example when there is recurrent contracting and when collaborators are in some way socialized in that collaborators can be excluded if they deviate from the norm.

\section{Open Knowledge Exchange}

As explained above, licensing can entail more or less restrictive arrangements by either discouraging or promoting the dissipation and use of knowledge. For example, in software development, the GNU General Public License (GPL) is used to more freely or openly distribute knowledge (or development result), although the possibility of appropriation of the results still exists in some way. As such, the GPL intends to guarantee one's freedom to share and change free software by obliging the transfer of the source code and all the right to use and modify the software (the source code in particular). Copyleft, as referred to before, can moreover be interpreted as a non-exclusive blanket license with a compulsory non-exclusive grantback blanket license (i.e. with sub-licensing). Thus, even an open knowledge exchange strategy can be described as a combination (architecture) of a number of essential license types (modules), as also presented in Figure 1.

Broadly speaking, open source models entail several distinct types of licensing schemes. In general, open source software can be considered as an incentive system for innovations, which takes a different approach than for example the patent system (Lerner \& Tirole, 2002a). Important to note is that open source is especially relevant for public good knowledge. Accordingly, von Hippel and von Krogh (2003) propose a "private-collective innovation model" that contains elements of both the private investment model(in which knowledge is appropriated privately) and the collective action model (with the emphasis on public knowledge), and can offer society the "best of both worlds". This model, in which privately developed results (e.g. a code in open source software) are freely revealed, might have similarities with the strategies adopted in collaborative innovation in general (Harhoff, Henkel, \& von Hippel, 2003; Raasch, Herstatt, \& Balka, 2009; von Hippel, 2007). On the one hand, "free" dissemination of knowledge to the public can be applicable to some cases, 
such as in the case of standardization projects. On the other hand, collaborating partners might implement an open knowledge exchange strategy with some partners but not with others.

\section{Layered Collaboration Scheme}

With an increasing number of participants involved in open collaborative innovation, it becomes more difficult to manage the exchange of knowledge. Therefore, it is generally acknowledged that one should aim at keeping the number of partners to a minimum. At the same time, it is clear that certain developments need the input of more (or even many) partners. If a collaborative innovation project consists of many partners, the work can be divided among the partners and over time. In this sense, certain "sub-collaborations" can arise within the overall collaborative innovation project. Furthermore, if some of the partners play a more central role than others, a layered collaboration scheme can take a more structural form with relatively fixed core members and outer member. Relatedly, there might be a "hub" organization in which one partner (i.e. the hub) takes a central role in the negotiation of agreements (European Commission, 2002). This is especially the case in international collaborations in which different national systems complicate the generic collaboration agreement. This can moreover be an effective way to deal with IPRs and licensing issues because these are not well covered by general agreements (e.g. the model consortium agreement of the "European Framework Programmes") that generally over-specify the terms (European Commission, 2002).

Effectively, a layered collaboration scheme entails a multi-partner collaborative innovation project in which the "core" consists of inner members that generally have a close relationship and adopt a strategy of open knowledge exchange, while the "periphery" consists of the outer mem- bers that adopt a specific knowledge exchange strategy among each other. More particularly, the inner members potentially adopt a specific and potentially different knowledge exchange strategy towards the outer members. Additionally, there needs to be particular arrangements for knowledge exchange with "non-members" in the market or general environment (as in the case of non-layered forms of open collaborative innovation). One example of a layered collaborative innovation project is the Bluetooth standardization consortium in which there are a few core members ${ }^{4}$ that set up the consortium and openly shared their knowledge to develop the Bluetooth standard. The periphery of this collaboration consists of many partners that adopt the developments of the core in a strict way, which is also a way for the core members to appropriate the results of the developments.

An important economic rationale for the existence of a layered collaboration scheme is dealing with the different roles that different partners have in a multi-partner collaborative innovation project in order to reach the common goal. Although it is essential to pool resources of all the partners to a certain extent, there is an asymmetry of contributions between the different partners. This means that a different exchange strategy is required for inner and outer members. In this sense, establishing an open knowledge sharing in the inner structure can economize on transaction costs because there are few costly contracts involved. The contributions of the core members relate to the core of the development in the collaborative innovation project and their open sharing therefore has to be compensated with a high degree of appropriation of the returns on this development. The open sharing in the core of the collaboration moreover deals with the "information paradox" (as does open sharing in general) in a more defined way, which is a way govern knowledge exchange in the collaboration. 


\section{Knowledge Exchange Strategies}

In order to govern knowledge exchange in open collaborative innovation, the knowledge exchange strategy in a collaboration can be either open or closed ${ }^{5}$, both within and outside the collaboration. It can furthermore be different (i.e. layered) for different levels of the collaboration. Accordingly, four possible general exchange strategies are in principle possible for collaborative innovation projects, namely: (a) open within and outside (labeled "public");(b) open within and closed outside (labeled "private"); (c) closed within and outside; and (d) a layered scheme with an open exchange with the core members, a moderate exchange with the outer members and a close exchange outside the collaboration. Table 2 gives these strategies in the order from a high to a low degree of open exchange. The "degree of knowledge exchange" refers to the amount of knowledge exchange and thus the degree of open exchange.

The "layered exchange strategy" potentially has some variation of its own but for the sake of simplicity that is not taken into account in this overview. Because the other exchange strategies need not to consist of many partners, the expected degrees of knowledge sharing with the outer members are put in parentheses. The "closed exchange strategy" with a restrictive exchange to all participants indicates a much formalized and therefore potentially tensed collaboration. The "open exchange strategy" has two main forms, namely a public one and a private one, which partly relates to the private and public innovation model as described above (von Hippel \& von Krogh, 2003).

\section{CONCLUSION}

This chapter presents some strategic considerations with respect to managing IP in open collaborative innovation. It thereby shows the important role of IPRs and their licensing as a way to protect knowledge that is used and developed and to govern its sharing in collaborations as a particular form of open innovation. In particular, different elementary/generic licensing types are presented and various governance "architectures" are presented as certain combinations of various "modules" of licenses, with a particular emphasis on "open" innovation models (e.g. related to "open source" innovation). This chapter thus provides a typology of basic licensing schemes that can serve as building blocks that can be combined to form more complex licensing arrangements. Finally, the chapter more generally proposes several distinct strategies for governing knowledge exchange in open collaborative innovation, including open exchange and layered schemes, which thereby facilitate managing open innovation more successfully.

Table 2. A typology of knowledge exchange strategies in open collaborative innovation

\begin{tabular}{|l|l|l|l|}
\hline \multirow{2}{*}{\begin{tabular}{|l}
$*$ \\
Knowledge exchange strategies
\end{tabular}} & \multicolumn{1}{c|}{$\begin{array}{c}\text { Internal }- \\
\text { Core members }\end{array}$} & $\begin{array}{c}\text { Internal }- \\
\text { Outer members }\end{array}$ & $\begin{array}{c}\text { External }- \\
\text { Outside }\end{array}$ \\
\cline { 2 - 4 } & High & (High) & High \\
\hline Open exchange strategy - public & High & (High) & Low \\
\hline Open exchange strategy - private & High & Moderate & Low \\
\hline Layered exchange strategy & Low & (Low) & Low \\
\hline Closed exchange strategy & & \\
\hline
\end{tabular}




\section{REFERENCES}

Afuah, A. (2003). Redefining firm boundaries in the face of the internet: Are firms really shrinking? Academy of Management Review, 28(1), 34-53.

Alexy, O., Criscuolo, P., \& Salter, A. (2009). Does IP strategy have to cripple open innovation? Sloan Management Review, 51(1), 71-77.

Andersen, B. (2004). If 'intellectual property rights' is the answer, what is the question? Revisiting the patent controversies. Economics of Innovation and New Technology, 13(5), 417-442. doi:10.1080/1043859042000188692

Arora, A., Fosfuri, A., \& Gambardella, A. (2001). Markets for Technology: The Economics of Innovation and Corporate Strategy. Cambridge, MA: MIT Press.

Arrow, K. J. (1962). Economic welfare and the allocation of resources for invention. In National Bureau of Economic Research (Ed.), The Rate and Direction of Inventive Activity: Economic and Social Factors (pp. 609-625). Princeton, NJ: Princeton University Press.

Bainbridge, D. I. (2002). Intellectual Property (5th ed.). Harlow: Longman.

Bessy, C., \& Brousseau, E. (1998). Technology licensing contracts features and diversity. International Review of Law and Economics, 18, 451-489. doi:10.1016/S0144-8188(98)00018-0

Bogers, M. (2011). The open innovation paradox: Knowledge sharing and protection in R\&D collaborations. European Journal of Innovation Management, 14(1), 93-117. doi:10.1108/14601061111104715

Bogers, M., \& West, J. (2010). Contrasting innovation creation and commercialization within open, user and cumulative innovation. Working Paper,http://ssrn.com/abstract=1751025.
Boldrin, M., \& Levine, D. K. (2008). Against Intellectual Monopoly. Cambridge, MA: Cambridge University Press.

Chesbrough, H. W. (2003a). Open Innovation: The New Imperative for Creating and Profiting from Technology. Boston, MA: Harvard Business School Press.

Chesbrough, H. W. (2003b). The logic of open innovation: Managing intellectual property. California Management Review, 45(3), 33-58.

Cohen, W. M., Nelson, R. R., \& Walsh, J. P. (2000). Protecting their intellectual assets: Appropriability conditions and why US manufacturing firms patent (or not). NBER Working Paper 7552.

Conner, K. R., \& Prahalad, C. K. (1996). A resource-based theory of the firm: Knowledge versus opportunism. Organization Science, 7(5), 477-501. doi:10.1287/orsc.7.5.477

Coriat, B., \& Orsi, F. (2002). Establishing a new intellectual property rights regime in the United States: Origins, content and problems. Research Policy, 31(8-9), 1491-1507. doi:10.1016/S00487333(02)00078-1

Cowan, R., David, P. A., \& Foray, D. (2000). The explicit economics of knowledge codification and tacitness. Industrial and Corporate Change, 9(2), 211-253. doi:10.1093/icc/9.2.211

Dahlander, L., \& Gann, D. M. (2010). How open is innovation? Research Policy, 39(6), 699-709. doi:10.1016/j.respol.2010.01.013

Davis, L. (2004). Intellectual property rights, strategy and policy. Economics of Innovation and New Technology, 13(5), 399-415. doi:10.1080/1043859042000188683

de Laat, P. B. (2005). Copyright or copyleft? An analysis of property regimes for software development. Research Policy, 34(10), 1511-1532. doi:10.1016/j.respol.2005.07.003 
Dosi, G., Marengo, L., \& Pasquali, C. (2006). How much should society fuel the greed of innovators? On the relations between appropriability, opportunities and rates of innovation. Research Policy, 35(8), 1110-1121.doi:10.1016/j. respol.2006.09.003

Eisenberg, R. S. (1996). Public research and private development: Patents and technology transfer in government-sponsored research. Virginia Law Review, 82(8),1663-1727. doi:10.2307/1073686

Enkel, E., Gassmann, O., \& Chesbrough, H. W. (2009). Open R\&D and open innovation: Exploring the phenomenon. $R \&$ D Management, 39(4), 311-316. doi:10.1111/j.1467-9310.2009.00570.x

European Commission. (2001). IPR (Intellectual Property Rights) Aspects of Internet Collaborations (No. EUR 19456). Brussels: European Commission.

European Commission. (2002). Expert Group Report on: Role and Strategic Use of IPRs (Intellectual Property Rights) in International Research Collaborations (No. EUR 20230). Brussels: European Commission.

Gallini, N., \& Scotchmer, S. (2002). Intellectual property: When is it the best incentive mechanism? In Jaffe, A. B., Lerner, J., \& Stern, S. (Eds.), Innovation Policy and the Economy 2 (pp. 51-78). Cambridge, MA: MIT Press.

Gerlach, M. L. (1992). Alliance Capitalism: The Social Organization of Japanese Business. Berkeley, CA: University of California Press.

Granstrand, O. (1998). Towards a theory of the technology-based firm. Research Policy, 27(5), 465-489. doi:10.1016/S0048-7333(98)00067-5

Granstrand, O. (2000). The Economics and Management of Intellectual Property: Towards Intellectual Capitalism. Cheltenham, UK:Edward Elgar Publishing.
Granstrand, O.(Ed.).(2003). Economics, Law and Intellectual Property. Dordrecht, the Netherlands: Kluwer Academic Publishers.

Granstrand, O. (2004). The economics and management of technology trade: Towards a prolicensing era? International Journal of Technology Management, 27(2,3), 209-240.

Granstrand, O. (2011). Industrial Innovation Economics and Intellectual Property (6th ed.). Gothenburg, Sweden: Svenska Kulturkompaniet.

Granstrand, O., \& Sjölander, S. (1990). Managing innovation in multi-technology corporations. Research Policy, 19(1),35-60. doi:10.1016/00487333(90)90033-3

Grindley, P. C., \& Teece, D. J. (1997). Managing Intellectual Capital: Licensing and Cross-Licensing in Semiconductors and Electronics. California Management Review, 39(2), 8-41.

Hagedoorn, J. (2002). Inter-firm R\&D partnerships: An overview of major trends and patterns since 1960. Research Policy, 31(4), 477-492. doi:10.1016/S0048-7333(01)00120-2

Harhoff, D., Henkel, J., \& von Hippel, E. (2003). Profiting from voluntary information spillovers: How users benefit by freely revealing their innovations. Research Policy, 32(10), 1753-1769. doi:10.1016/S0048-7333(03)00061-1

Harison, E. (2004). Designed for Innovation: The Structure of IPR Regimes and the Evolution of Information Technologies. Paper presented at the DRUID Summer Conference 2004 on Industrial Dynamics, Innovation and Development. Elsinore, Denmark, June 14-16, 2004. Maastricht: MERIT, University of Maastricht.

Heller, M. A., \& Eisenberg, R. S. (1998). Can patents deter innovation? The anticommons in biomedical research. Science, 280(5364), 698-701. doi:10.1126/science.280.5364.698 
Henkel, J. (2006). Selective revealing in open innovation processes: The case of embedded Linux. Research Policy, 35(7), 953-969. doi:10.1016/j. respol.2006.04.010

Hertzfeld, H. R., Link, A. N., \& Vonortas, N. S. (2001). Intellectual Property Protection Mechanisms and Research Partnerships. Washington, D.C.: Center for International Science and Technology Policy, Elliott School of International Affairs, George Washington University.

Jaffe, A. B. (2000). The U.S. patent system in transition: Policy innovation and the innovation process. Research Policy, 29(4-5), 531-557.

Jaffe, A. B., \& Lerner, J. (2004). Innovation and Its Discontents: How Our Broken Patent System Is Endangering Innovation and Progress, and What to Do About It. Princeton, NJ: Princeton University Press.

Kale, P., Singh, H., \& Perlmutter, H. (2000). Learning and protection of proprietary assets in strategic alliances: Buildingrelational capital.StrategicManagement Journal, 21(3), 217-237. doi:10.1002/ (SICI)1097-0266(200003)21:3<217::AIDSMJ95>3.0.CO;2-Y

Kogut, B., \& Zander, U. (1993). Knowledge of the firm and evolutionary theory of the multinational corporation. Journal of International Business Studies, 24, 625-645. doi:10.1057/palgrave. jibs. 8490248

Laursen, K., \& Salter, A. (2006). Open for innovation: The role of openness in explaining innovation performance among U.K. manufacturing firms. Strategic Management Journal, 27(2), 131-150. doi:10.1002/smj.507

Lee, L. C., \& Davidson, J. S. (1993). Managing Intellectual Property Rights. New York: John Wiley \& Sons.
Lerner, J., \& Tirole, J. (2002a). Some simple economics of open source. The Journal of Industrial Economics, 50(2), 197-234. doi:10.1111/14676451.00174

Lerner, J., \& Tirole, J. (2002b). The scope of open source licensing. NBER working paper series, 9363.

Levin, R. C., Klevorick, A. K., Nelson, R. R., \& Winter, S. G. (1987). Appropriating the returns from industrial R\&D. Brookings Papers on Economic Activity, 14, 551-561.

Lichtenthaler, U. (2005). External commercialization of knowledge: Review and research agenda. International Journal of Management Reviews, 7(4), 231-255. doi:10.1111/j.14682370.2005.00115.x

Lichtenthaler, U., \& Ernst, H. (2007). External technology commercialization in large firms: Results of a quantitative benchmarking study. $R$ \& D Management, 37(5), 383-397. doi:10.1111/ j.1467-9310.2007.00487.x

Machlup, F. M., \& Penrose, E. T. (1950). The patent controversy in the nineteenth century. The Journal of Economic History, 10(1), 1-29.

Mazzoleni, R., \& Nelson, R. R. (1998). The benefits and costs of strong patent protection: Acontribution to the current debate. Research Policy, 27, 273-284. doi:10.1016/S0048-7333(98)00048-1

Megantz, R. C. (1996). How to Licence Technology. New York: John Wiley \& Sons.

Mohr, J. J., \& Sengupta, S. (2002). Managing the paradox of inter-firm learning: The role of governance mechanisms. Journal of Business and Industrial Marketing, 17(4), 282-301. doi:10.1108/08858620210431688

Monteverde, K. (1995). Technical dialog as an incentive for vertical integration in the semiconductor industry. Management Science, 41(10), 1624-1638. doi:10.1287/mnsc.41.10.1624 
Oxley, J. E., \& Sampson, R. C. (2004). The scope and governance of international R\&D alliances. Strategic Management Journal, 25, 723-749. doi:10.1002/smj.391

Polanyi, M. (1958). Personal Knowledge: Towards a Post-Critical Philosophy. Chicago, IL: Routledge \& Kegan Paul.

Polanyi, M. (1967). The Tacit Dimension. New York: Anchor Books.

Raasch, C., Herstatt, C., \& Balka, K. (2009). On the open design of tangible goods. $R \& D$ Management, 39(4), 382-393. doi:10.1111/j.14679310.2009.00567.x

Shapiro, C. (2001). Navigating the patent thicket: Cross licenses, patent pools, and standard setting . In Jaffe, A. B., Lerner, J., \& Stern, S. (Eds.), Innovation Policy and the Economy (Vol. 1, pp. 119-150). Cambridge, MA: MIT Press.

Teece, D. J. (1998). Capturing value from knowledge assets: The new economy, markets for know-how, and intangible assets. California Management Review, 40(3), 55-79.

Teece, D. J. (2000). Managing Intellectual Capital: Organizational, Strategic, and Policy Dimensions. Oxford: Oxford University Press.

van de Vrande, V., de Jong, J. P. J., Vanhaverbeke, W., \& de Rochemont, M. (2008). (in press). Open innovation in SMEs: Trends, motives and management challenges. [Corrected Proof.]. Technovation.

von Hippel, E. (1994). 'Sticky information' and the locus of problem solving: Implications for innovation. Management Science, 40(4), 429-439. doi:10.1287/mnsc.40.4.429

von Hippel, E. (2007). Horizontal innovation networks--by and for users. Industrial and Corporate Change, 16(2), 293-315. doi:10.1093/ icc/dtm005 von Hippel, E., \& von Krogh, G. (2003). Open source software and the 'private-collective' innovation model: Issues for organization science. $\mathrm{Or}$ ganization Science, 14(2), 209-223. doi:10.1287/ orsc.14.2.209.14992

West, J. (2003). How open is open enough? Melding proprietary and open source platform strategies. Research Policy, 32(7), 1259-1285. doi:10.1016/S0048-7333(03)00052-0

West, J., Vanhaverbeke, W., \& Chesbrough, H. W. (2006). Open innovation: A research agenda. In H. W. Chesbrough, W. Vanhaverbeke \& J. West (Eds.), Open Innovation: Researching a New Paradigm (pp. 285-307). Oxford, UK: Oxford University Press.

Williamson, O.E.(1991). Comparative economic organization: The analysis of discrete structural alternatives. Administrative Science Quarterly, 36(4), 269-296. doi:10.2307/2393356

WIPO. (2001). WIPOIntellectual Property Handbook: Policy, Law and Use. Geneva, Switzerland: World Intellectual Property Organization.

\section{ADDITIONAL READING}

Alexy, O., Criscuolo, P., \& Salter, A. (2009). Does IP strategy have to cripple open innovation? Sloan Management Review, 51(1), 71-77.

Andersen, B. (Ed.). (2006). Intellectual Property Rights: Innovation, Governance and the Institutional Environment. Cheltenham, UK: Edward Elgar Publishing.

Arora, A. (2002). Licensing tacit knowledge: Intellectual property rights and the market for knowhow. Economics of Innovation and New Technology,4(1),41-59. doi:10.1080/10438599500000013 
Arora, A., Fosfuri, A., \& Gambardella, A. (2001). Markets for Technology: The Economics of Innovation and Corporate Strategy. Cambridge, MA: MIT Press.

Bainbridge, D. I. (2002). Intellectual Property (5th ed.). Harlow: Longman.

Bednarek, M., \& Ineichen, M. (2004). Patent pools as an alternative to patent wars in emerging sectors. Intellectual Property and Technology Law Journal, 16(7), 1-5.

Bekkers, R., Duysters, G., \& Verspagen, B. (2002). Intellectual property rights, strategic technology agreements and market structure: The case of GSM. Research Policy, 31(7), 1141-1161. doi:10.1016/S0048-7333(01)00189-5

Bekkers, R., \& West, J. (2009). The limits to IPR standardization policies as evidenced by strategic patenting in UMTS. Telecommunications Policy, 33(1-2), 80-97.doi:10.1016/j.telpol.2008.11.003

Besen, S. M., \& Raskind, L. J. (1991). An introduction to the law and economics of intellectual property. The Journal of Economic Perspectives, 5(1), 3-27.

Bogers, M. (2011). The open innovation paradox: Knowledge sharing and protection in R\&D collaborations. European Journal of Innovation Management, 14(1), 93-117. doi:10.1108/14601061111104715

Bogers, M., \& West, J. (2010). Contrasting innovation creation and commercialization within open, user and cumulative innovation, Working Paper,http://ssrn.com/abstract=1751025.

Boldrin, M., \& Levine, D. K. (2008). Against Intellectual Monopoly. Cambridge, MA: Cambridge University Press.

Caloghirou, Y., Vonortas, N. S., \& Ioannides, S. (2004). European Collaboration in Research and Development: Business Strategy and Public Policy. Cheltenham: Edward Elgar Publishing.
Chesbrough, H. W., Vanhaverbeke, W., \& West, J. (Eds.). (2006). Open Innovation: Researching a New Paradigm. Oxford, UK: Oxford University Press.

Coriat, B., \& Orsi, F. (2002). Establishing a new intellectual property rights regime in the United States: Origins, content and problems. Research Policy, 31, 1491-1507. doi:10.1016/S00487333(02)00078-1

Dahlander, L., \& Gann, D. M. (2010). How open is innovation? Research Policy, 39(6), 699-709. doi:10.1016/j.respol.2010.01.013

David, P.A. (1998). Common agency contracting and the emergence of 'open science' institutions. The American Economic Review, 88(2), 15-21.

Davis, L. (2004). Intellectual property rights, strategy and policy. Economics of Innovation and New Technology, 13(5), 399-415. doi:10.1080/1043859042000188683

Encaoua, D., Guellec, D., \& Martínez, C. (2006). Patent systems for encouraging innovation: Lessons from economic analysis. Research Policy, 35(9), 1423-1440. doi:10.1016/j.respol.2006.07.004

Enkel, E., Gassmann, O., \& Chesbrough, H. W. (2009). Open R\&D and open innovation: Exploring the phenomenon. $R \& D$ Management, 39(4), 311-316. doi:10.1111/j.1467-9310.2009.00570.x

European Commission. (1999). ETAN Working Paper: Strategic dimensions of Intellectual Property Rights in the context of S\& T Policy (No. EUR 18914). Brussels: European Commission.

European Commission. (2001). IPR (Intellectual Property Rights) Aspects of Internet Collaborations (No. EUR 19456). Brussels: European Commission. 
European Commission. (2002). Expert Group Report on: Role and Strategic Use of IPRs (Intellectual Property Rights) in International Research Collaborations (No. EUR 20230). Brussels: European Commission.

European Commission. (2003). Expert Group Report on: Strategic Use and Adaptation of Intellectual Property Rights Systems in Information and Communications Technologies-based Research (No. EUR 20734). Brussels: European Commission.

Foray, D. (2004). The Economics of Knowledge. Cambridge, MA: MIT Press.

Foray, D., \& Steinmueller, W. E. (2003). On the economics of R\&D and technological collaborations: Insights and results from the project Colline. Economics of Innovation and New Technology, 12(1), 77-91. doi:10.1080/10438590303118

Gallini, N., \& Scotchmer, S. (2002). Intellectual property: When is it the best incentive mechanism? In Jaffe, A. B., Lerner, J., \& Stern, S. (Eds.), Innovation Policy and the Economy 2 (pp. 51-78). Cambridge, MA: MIT Press.

Gambardella, A., Harhoff, D., \& Verspagen, B. (2008). The value of European patents. European Management Review, 5(2), 69-84.

Gerlach, M. L. (1992). Alliance Capitalism: The Social Organization of Japanese Business. Berkeley, CA: University of California Press.

Giuri, P., Mariani, M., Brusoni, S., Crespi, G., Francoz, D., \& Gambardella,A. (2007). Inventors and invention processes in Europe: Results from the PatVal-EU survey. Research Policy, 36(8), 1107-1127. doi:10.1016/j.respol.2007.07.008

Granstrand, O. (2000). The Economics and Management of Intellectual Property: Towards Intellectual Capitalism. Cheltenham, UK:Edward Elgar Publishing.
Granstrand, O.(Ed.).(2003). Economics, Law and Intellectual Property. Dordrecht, the Netherlands: Kluwer Academic Publishers.

Granstrand, O. (2004). Innovation and intellectual property rights . In Fagerberg, J., Mowery, D. C., \& Nelson, R. R. (Eds.), The Oxford Handbook of Innovation. New York: Oxford University Press.

Granstrand, O. (2006). Fair and reasonable royalty rate determination. LES Nouvelles, XLI(3), 179-181.

Granstrand, O. (2006). Intellectual property rights for governance in and of innovation systems . In Andersen, B. (Ed.), Intellectual Property Rights: Innovation, Governance and the Institutional Environment (pp.311-343). Cheltenham: Edward Elgar Publishing.

Granstrand, O. (2011). Industrial Innovation Economics and Intellectual Property (6th ed.). Gothenburg, Sweden: Svenska Kulturkompaniet.

Granstrand, O., \& Lindmark, S. (2002). Technology Collaborations in Corporate Innovation Systems. Gothenburg, Sweden: Department of Industrial Management and Economics, Chalmers University of Technology.

Hagedoorn, J. (2003). Sharing intellectual property rights: An exploratory study of joint patenting amongst companies. Industrial and Corporate Change, 15(5), 1035-1050. doi:10.1093/ icc/12.5.1035

Harison, E., \& Cowan, R. (2004). On substitution of intellectual property and free disclosure: An analysis of $R \& D$ strategies in software technologies. Economics of Innovation and New Technology, 13(5), 477-487. doi:10.1080/1043859042000253581

Henkel, J. (2009). Champions of revealing: The role of open source developers in commercial firms. Industrial and Corporate Change, 18(3), 435-447. doi:10.1093/icc/dtn046 
Hertzfeld, H. R., Link, A. N., \& Vonortas, N. S. (2001). Intellectual Property Protection Mechanisms and Research Partnerships. Washington, D.C.: Center for International Science and Technology Policy, Elliott School of International Affairs, George Washington University.

Jaffe, A. B., \& Lerner, J. (2004). Innovation and Its Discontents: How Our Broken Patent System Is Endangering Innovation and Progress, and What to Do About It. Princeton, NJ: Princeton University Press.

Jaffe, A. B., \& Trajtenberg, M. (Eds.). (2002). Patents, Citations, and Innovations: A Window on the Knowledge Economy. Cambridge, MA: MIT Press.

Lee, L. C., \& Davidson, J. S. (1993). Managing Intellectual Property Rights. New York: John Wiley \& Sons.

Lerner, J., \& Tirole, J. (2002). Some simple economics of open source. The Journal of Industrial Economics, 50(2), 197-234. doi:10.1111/14676451.00174

Luukkonen, T. (2002). Technology and market orientation in company participation in the EU framework programme. Research Policy, 31(3), 437-455. doi:10.1016/S0048-7333(01)00118-4

Machlup, F. M., \& Penrose, E. T. (1950). The patent controversy in the nineteenth century. The Journal of Economic History, 10(1), 1-29.

Mansfield, E. (1986). Patents and innovation: An empirical study. Management Science, 32(2), 173-181. doi:10.1287/mnsc.32.2.173

Mazzoleni, R., \& Nelson, R. R. (1998). The benefits and costs of strong patent protection: Acontribution to the current debate. Research Policy, 27, 273-284. doi:10.1016/S0048-7333(98)00048-1

Megantz, R. C. (1996). How to Licence Technology. New York: John Wiley \& Sons.
Ordover, J. A. (1991). A patent system for both diffusion and exclusion. The Journal of Economic Perspectives, 5(1), 43-60.

Poltorak, A. I., \& Lerner, P. J. (2004). Essentials of Licensing Intellectual Property. Hoboken, NJ: John Wiley \& Sons.

Shapiro, C. (1985). Patent licensing and R\&D rivalry. The American Economic Review, 75(2), 25-30.

Shapiro, C. (2001). Navigating the patent thicket: Cross licenses, patent pools, and standard setting . In Jaffe, A. B., Lerner, J., \& Stern, S. (Eds.), Innovation Policy and the Economy (Vol. 1, pp. 119-150). Cambridge, MA: MIT Press.

Stoneman, P. (Ed.). (1995). Handbook of the Economics of Innovation and Technological Change. Oxford: Blackwell.

Takenaka, T. (Ed.). (2008). Patent Law and Theory: A Handbook of Contemporary Research. Cheltenham, UK: Edward Elgar.

Teece, D. J. (1998). Capturing value from knowledge assets: The new economy, markets for know-how, and intangible assets. California Management Review, 40(3), 55-79.

Teece, D. J. (2000). Managing Intellectual Capital: Organizational, Strategic, and Policy Dimensions. Oxford: Oxford University Press.

von Hippel, E. (2005). Democratizing Innovation. Cambridge, MA: MIT Press.

von Hippel, E., \& von Krogh, G. (2003). Open source software and the 'private-collective' innovation model: Issues for organization science. Organization Science, 14(2), 209-223. doi:10.1287/ orsc.14.2.209.14992

West, J., \& Gallagher, S. (2006). Challenges of open innovation: The paradox of firm investment in open-source software. $R \&$ D Management, 36(3), 319-331. doi:10.1111/j.1467-9310.2006.00436.x 
WIPO.(2001). WIPO Intellectual Property Handbook: Policy, Law and Use. Geneva, Switzerland: World Intellectual Property Organization.

\section{KEY TERMS AND DEFINITIONS ${ }^{6}$}

Blanket License:Alicense agreement in which the licensor grants permission to the licensee to use any rights related to a particular area of future developments of the licensed technology.

Collaborative Innovation (Process): An innovation (process) involving several human individuals as creators. A collaboration is either intra- or inter-organizational (i.e. open) depending on whether the (individual) creators belong to the same or different organization(s), respectively.

Cross-License: The mutual exchange of licenses between two or more parties (as both licensor and licensee).

Grant-Back License: A license in which the licensor obtains the right, from the licensee, to improvement made by the licensee.

Information Paradox: The inherent problem that information or know-how cannot be described by its prospective seller without effective transfer when disclosed for inspection of a prospective buyer.

Innovation: Anything new (to all) and useful to some (short hand definition).

Intellectual Property (IP): An intangible property or asset that results from the creation of the human mind, including inventions and designs as well as literary or artistic works.

Intellectual Property Right (IPR): A legal instrument that protects certain creations of the human mind, including patent rights, trade secret rights, trademark rights, copyrights, design rights, database rights, and a few more specific ones.

Invention: Any human creation new to all and potentially useful to some.

Joint License: A license agreement in which two or more parties jointly offer permission to use a particular part of their (often complementary) IP to a third party, possibly involving an external administrator that acts as coordinator.

License: A permission granted by the owner of an IPR (the licensor) to another legal entity (the licensee) to use underlying IP in a particular way and under certain restrictive conditions.

Open Collaborative Innovation: Interorganizational collaborative innovation.

Packet/Block License: A bundle of licenses offered by a licensor to a licensee, in contrast to licenses to individual pieces of IPRs.

Patent Pool: A contractual arrangement between two or more parties to cross-license parts of their current or future patent portfolios related to certain technologies to one another or to third parties.

Patent Thicket: A set of closely related and possibly overlapping patent rights to a certain technology, thereby requiring anyone that wish to use, build on or commercialize that technology to obtain licenses from various patent holders.

Sub-License: A license in which the licensor permits the licensee to license the underlying IP to another licensee.

Technology: Technical knowledge or knowhow.

\section{ENDNOTES}

$1 \quad$ Shapiro (2001) defines a patent thicket as an overlapping set of patent rights requiring that those seeking to commercialize new technology obtain licenses from multiple patentees.

2 The basic requirements for patentability are novelty, inventive step and industrial application (see e.g. Bainbridge, 2002 for a more detailed elaboration).

3 An example of such more complex arrangement is the GNU General Public License that intends to guarantee one's freedom to share and change free software by obliging 
the transfer of the source code and all the right to use and modify the software (the source code in particular).

4 Agere, Ericsson, IBM, Intel, Microsoft, Motorola, Nokia and Toshiba.
5 In practice, beyond the open/closed dichotomy, degrees of openness are also possible (cf. Granstrand \& Sjölander, 1990; Laursen $\&$ Salter, 2006).

6 Some definitions are derived from Granstrand $(2000,2011)$. 


\section{Open Innovation in Firms and Public Administrations:}

\section{Technologies for Value Creation}

Carmen de Pablos Heredero

Universidad Rey Juan Carlos de Madrid, Spain

David López Berzosa

IE Business School, Spain 


\author{
Managing Director: \\ Lindsay Johnston \\ Book Production Manager: \\ Sean Woznicki \\ Development Manager: \\ Joel Gamon \\ Development Editor: \\ Myla Harty \\ Acquisitions Editor: \\ Erika Carter \\ Typesetter: \\ Christopher Shearer \\ Print Coordinator: Jamie Snavely \\ Cover Design: \\ Nick Newcomer \\ Published in the United States of America by \\ Information Science Reference (an imprint of IGI Global) \\ 701 E. Chocolate Avenue \\ Hershey PA 17033 \\ Tel: 717-533-8845 \\ Fax: 717-533-8661 \\ E-mail: cust@igi-global.com \\ Web site: http://www.igi-global.com
}

Copyright $(0) 2012$ by IGI Global. All rights reserved. No part of this publication may be reproduced, stored or distributed in any form or by any means, electronic or mechanical, including photocopying, without written permission from the publisher. Product or company names used in this set are for identification purposes only. Inclusion of the names of the products or companies does not indicate a claim of ownership by IGI Global of the trademark or registered trademark.

\title{
Library of Congress Cataloging-in-Publication Data
}

Open innovation in firms and public administrations: technologies for value creation / Carmen de Pablos Heredero and David Lopez, editors.

p. $\mathrm{cm}$.

Includes bibliographical references and index.

Summary: "This book analyzes open innovation in a global context and proposes business models and institutional actors that promote the development of open innovation in firms, Institutions and public administrations worldwide"--Provided by publisher.

ISBN 978-1-61350-341-6 (hbk.) -- ISBN 978-1-61350-342-3 (ebook) -- ISBN 978-1-61350-343-0 (print \& perpetual access) 1. Technological innovations--Management. 2. Diffusion of innovations--Management. 3. New products. 4. Organizational effectiveness. 5. Knowledge management. 6. Intellectual capital--Management. I. Pablos Heredero, Carmen de. II. Lopez, David, 1973-

HD45.O63 2012

658.4'063--dc23

2011031959

British Cataloguing in Publication Data

A Cataloguing in Publication record for this book is available from the British Library.

All work contributed to this book is new, previously-unpublished material. The views expressed in this book are those of the authors, but not necessarily of the publisher. 